\title{
Allium sativum L. regulates in vitro IL-17 gene expression in human peripheral blood mononuclear cells
}

\author{
Mouna Moutia ${ }^{1,2}$, Fouad Seghrouchni ${ }^{3}$, Omar Abouelazz ${ }^{4}$, Anass Elouaddari ${ }^{5}$, Abdellah Al Jahid ${ }^{5}$, \\ Abdelhalim Elhou ${ }^{6}$, Sellama Nadifi ${ }^{4}$, Jamal Jamal Eddine ${ }^{5}$, Norddine Habti ${ }^{1,2}$ and Abdallah Badou ${ }^{4,6^{*}}$
}

\begin{abstract}
Background: Allium sativum L. (A.S.) "garlic", one of the most interesting medicinal plants, has been suggested to contain compounds that could be beneficial in numerous pathological situations including cancer. In this work, we aimed to assess the immunomodulatory effect of A.S. preparation on human peripheral blood mononuclear cells from healthy individuals.

Methods: Nontoxic doses of A.S. were identified using MTT assay. Effects on CD4+ or CD8+ T lymphocyte proliferation were studied using flow cytometry. The effect of A.S. on cytokine gene expression was studied using qRT-PCR. Finally, qualitative analysis of A.S. was performed by HPLC approach. Data were analyzed statistically by one-way ANOVA test.

Results: The nontoxic doses of A.S. preparation did not affect neither spontaneous nor TCR-mediated CD4+ or CD8+ T lymphocyte proliferation. Interestingly, A.S. exhibited a statistically significant regulation of IL-17 gene expression, a cytokine involved in several inflammatory and autoimmune diseases. In contrast, the expression of $\mathrm{IL}-4$, an anti-inflammatory cytokine, was unaffected. Qualitative analysis of A.S. ethanol preparation indicated the presence of three polyphenol bioactive compounds, which are catechin, vanillic acid and ferulic acid.

Conclusion: The specific inhibition of the pro-inflammatory cytokine, IL-17 without affecting cell proliferation in human PBMCs by the Allium sativum L. preparation suggests a potential valuable effect of the compounds present in this plant for the treatment of inflammatory diseases and cancer, where $\mathrm{IL}-17$ is highly expressed. The individual contribution of these three compounds to this global effect will be assessed.
\end{abstract}

Keywords: Allium sativum, Peripheral blood mononuclear cells, Anti-inflammation, Cytokines, Gene expression, Cell proliferation, Cell toxicity

\section{Background}

T cells represent about $70 \%$ of human Peripheral Blood Mononuclear Cells (PBMCs), in addition to monocytes, natural killer "NK" cells and B cells. Among T lymphocytes, CD4+ T cells are subdivided into various subpopulations such as Th1, Th2 and Th17 cells. Each of these subpopulations has its own set of immunological

\footnotetext{
* Correspondence: abdallahbadou@yahoo.com

${ }^{4}$ Cellular and Molecular Pathology Laboratory, Faculty of Medicine and

Pharmacy, Hassan II University, 19 Rue Tarik Ibnou Ziad, B.P. 9154 Casablanca, Morocco

${ }^{6}$ Research Team Health and Environment, Cadi Ayyad University, Polydisciplinary Faculty, Safi, Morocco

Full list of author information is available at the end of the article
}

functions, allowed by a specific group of produced cytokines. For instance, Th1 cells are in charge of intracellular pathogen eradication [1, 2]; but are also involved in the progress of autoimmune diseases and chronic inflammatory disorders [3]. They are characterized by high secretion of IFN- $\gamma$ and IL-2. Th2 cells are implicated in humoral immunity and provide protection against parasites. They are engaged in human allergic inflammation; its initiation, maintenance and amplification [4] via the production of IL-4, IL-10 and IL-13 $[4,5]$. Th17 are involved in the clearance of extracellular bacteria and fungi, due to their capacity to recruit and activate Neutrophils [6]. They are known for their production 
of IL-17A and IL-17 F. However, Th17 cells are also implicated in promoting the pathogenesis of cancer [7], several autoimmune and inflammatory diseases [8]; such as rheumatoid arthritis, multiple sclerosis, inflammatory bowel disease, psoriasis and contact dermatitis $[9,10]$. Our main interest is to identify phyto-molecules capable of regulating specific pro-inflammatory cytokines such as IL-17, which is implicated in various pathological situations including autoimmunity [8] and cancer [7, 9, 10].

Allium sativum L., a member of the Liliaceae family, is used universally as a flavoring agent in traditional medicine and to enhance physical and mental health [11-15]. Some reports also showed that a protein fraction of aged A.S. extract enhanced NK cell activity and cytotoxicity of macrophages towards tumor cells [16]. Another study demonstrated that ingestion of A.S. oil modulated the production of $\mathrm{T}$ helper cytokines in rat cervical lymph nodes [17]. Accordingly, A.S. and its specific ingredients, organosulphur compounds, are thought to affect the immune system [18].

In this paper, we aimed to assess the immunomodulatory effect of A.S. extract on human peripheral blood mononuclear cells. Doses of A.S., which did not cause cytotoxicty and did not affect cell proliferation, exhibited a marked regulation of the expression of the proinflammatory cytokine IL-17, known to be involved in numerous autoimmune and inflammatory diseases.

\section{Methods}

\section{A.S. extract preparation}

Allium sativum L. "garlic" bulbs were harvested from a botanical garden in the Faculty of Medicine and Pharmacy of Casablanca, Morocco. The plant was identified by a professor of Botany affiliated to the Biology department of the Polydisciplinary Faculty of Safi. A voucher of the plant specimen has been deposited in the herbarium of the department of Botany of the Scientific Institute of Rabat, Morocco under the reference number 97997. One-hundred grams of peeled dry garlic bulbs were mashed and incubated in ethanol (Sigma, USA) for $24 \mathrm{~h}$ (twice) at room temperature. Extracts were then concentrated by rotary. The obtained ethanolic extracts were stored at $-20 \mathrm{C}^{\circ}$ until use.

\section{Analysis of polyphenols by HPLC}

Qualitative analysis of standard phenolic compounds in A.S. ethanolic extract was performed using high performance liquid chromatography (HPLC) type JASCO PU-1580, equipped with a UV detector / Vis type JASCO $875 \mathrm{UV}$ and a data treatment station Azur version 3.0.3.0. The extract was evaporated to dryness at $40{ }^{\circ} \mathrm{C}$ and then taken up with a mixture of distilled water acetonitril (88-12\%). After vigorous stirring, mixtures were filtered by passing the solution through Whattman nylon membrane. Analysis conditions used were: Column: C18 (1.7 $\mu \mathrm{m} \mathrm{2,1 \times 150} \mathrm{mm),} \mathrm{UV} \mathrm{Wavelength:} 285 \mathrm{~nm}$, $1 \mathrm{ml} / \mathrm{min}$, gradient elution program was set as water /acetonitrile (88-12\%). The solution of the polyphenol mixture: Catechin, rutin, vanillin, vanillic acid, caffeic acid, syringic acid and ferulic acid was prepared by dissolving 1-5 $\mathrm{mg}$ of each polyphenol in $1 \mathrm{ml}$ of the acetonitril water $12-88 \%$. The final solution was filtered through a Whattman nylon membrane $0.22 \mu \mathrm{m}$.

\section{PBMC preparation and cell culture}

Peripheral blood mononuclear cells "PBMCs" were separated from fresh venous blood collected from healthy donors as previously described [19]. PBMCs isolation was performed by centrifugation on Ficoll- histopaque 1077 (Sigma, USA), at $900 \mathrm{~g}$ for $25 \mathrm{~min}$ at $18-20{ }^{\circ} \mathrm{C}$, then washed three times by centrifugation, and suspended in RPMI 1640 media (sigma, USA) with L-glutamine supplemented with $10 \%$ heat inactivated newborn calf serum (sigma, USA), $26.3 \mathrm{~g} / \mathrm{l}$ penicillin and $4.2 \mathrm{~g} / \mathrm{l}$ streptomycin. Cells were counted using a hemocytometer and standard Trypan blue exclusion method and observed under microscopy. Cells were harvested in plat culture at $37{ }^{\circ} \mathrm{C}$ in a humid atmosphere containing $5 \% \mathrm{CO}_{2}$ (Heracell $150 \mathrm{i}$ incubator $\mathrm{CO}_{2}$, Thermosciences, France) with different doses of A.S. preparation, with or without $5 \mu \mathrm{g} / \mathrm{ml}$ of phytohaemagglutinin (PHA; Sigma, USA) or plat bound monoclonal anti-CD3 (Okt3, $0.1 \mu \mathrm{g} / \mathrm{ml})$.

\section{MTT assay}

Cytotoxicity of A.S. extract to PBMCs was evaluated by MTT (3-(4, 5 dimethylthiazol-2-yl)-2, 5 diphenyltetrazolium bromide) assay $[19,20]$. The test was performed in 96-well plates (Hiwaka, Japan). Triplicate cultures in $200 \mu \mathrm{l}$ of cell suspension $\left(10^{5}\right.$ cells/well) were incubated in the presence of different doses of A.S. extract with or without stimulation using PHA or anti-human CD3 Okt3 monoclonal Ab. After 4 days of culture, $20 \mu \mathrm{l}$ of MTT solution ( $5 \mathrm{mg} / \mathrm{ml}$, Sigma, USA) was added to the wells and incubated for additional $4 \mathrm{~h}$ under the same conditions. After removing the plates and centrifuging them at $800 \times \mathrm{g}$ for $20 \mathrm{~min}$, supernatant was removed and blue formazan crystals were solubilized by adding $100 \mu \mathrm{l}$ of DMSO (Sigma, USA) under agitation. Optical Density of cells with A.S. extract was compared to that of control cells. Low optical density readings reflected low coloration intensity, due to the inability of nonviable cells to metabolize MTT salts.

\section{Proliferation assay}

PBMCs $\left(10^{6} \mathrm{cell} / \mathrm{ml}\right)$ were harvested in 96-well plates. A.S. extract was used at final concentrations of 1 and $2 \mu \mathrm{g} / \mathrm{ml}$, with or without PHA and with or without antiCD3 (Okt-3). Cells were labeled before culture with 5, 
6-carboxyfluorescein diacetate succinimidyl ester (CFSE) (Sigma, USA) at a concentration of $5 \mu \mathrm{M}$, according to a previous paper [21]. Afterward, labeled cells were washed twice with RPMI containing $5 \%$ heat inactivated newborn calf serum. After 4 days of culture, PBMCs were labeled with Anti-CD4 (PrCP, BDBiosciences, France) and antiCD8 (APC BD Biosciences, France), in order to evaluate proliferation of $\mathrm{CD} 4+$ and $\mathrm{CD} 8+$ lymphocyte subsets. Analyses were performed using FACS (BD FACSCalibur Flow Cytometer, BD Biosciences, France) and FlowJo software (Ashland, USA). One hundred thousand events were analyzed per sample.

\section{Gene expression quantification by RT-qPCR Total RNA isolation}

TRIzol (Sigma, France) was used to isolate total ARN from cells cultured for $18 \mathrm{~h}$ with different doses of A.S. extract in the presence or absence of PHA. Isolated RNA was solubilized in DEPC Treated Water (Invitrogene, France) and measured with spectrophotometer (NanoVue $^{\mathrm{Tm}}$ Plus Spectrophotometer GE Healthcare UK Limited, UK).

\section{Reverse Transcription (RT)}

$0.5 \mu \mathrm{g}$ of total ARN was used to synthesize cDNA using M-MLV reverse transcriptase (Reverse Transcriptase Super Scripte III, 10000 units, Invitrogene, France) in a $20 \mu \mathrm{l}$ reaction mixture according to the manufacturer's instructions. $1 \mu \mathrm{l}$ of oligo $\mathrm{dT}_{20}(50 \mu \mathrm{M})$ and $1 \mu \mathrm{l}$ of dNTP (10 mM of each) were added and the mixture was incubated at $65{ }^{\circ} \mathrm{C}$ for $5 \mathrm{~min}$ to break the secondary structure of RNA; and then put on ice for $5 \mathrm{~min}$. $4 \mu \mathrm{l}$ of 5X Reverse Transcriptase buffer, $1 \mu \mathrm{l}$ de DTT (100 mM), $1 \mu \mathrm{l}$ of RNase Inhibitor (RNasin OUT 5000 units, Invitrogene, France) and $1 \mu \mathrm{l}$ of M-MLV reverse transcriptase were subsequently added and the mixture was incubated at $50{ }^{\circ} \mathrm{C}$ for $60 \mathrm{~min}$, then $70{ }^{\circ} \mathrm{C}$ for $15 \mathrm{~min}$.

\section{Real-time PCR assays}

Amplifications were performed using Syber ${ }^{\bullet}$ Green PCR Master mix (Applied Biosystems ${ }^{\mathrm{TM}}$, life Technologies, France) as recommended by the manufacturer's manual. Using primers at $500 \mathrm{nM}$ for all genes, PCR was programmed as follows: $10 \mathrm{~min}$ at $95{ }^{\circ} \mathrm{C}$ for polymerase activation and sample denaturation; then 40 cycles of $15 \mathrm{~s}$ at $95{ }^{\circ} \mathrm{C}$ and $60 \mathrm{~s}$ at $60{ }^{\circ} \mathrm{C}$ for annealing and extension. Relative quantification of gene expression was analyzed by real-time PCR using real time Fast 7500 (Applied Biosystems $^{\mathrm{TM}}$ ). $\beta$-actin was used as internal control. Primers used are as follows; $\beta$-actin: forward GAGATGGCC ACGGCTGCTT, reverse GCCACAGGACTCCATGC CCA (transcript size: $446 \mathrm{bp}$ ), IL-17: forward ATCTC CACCGCAATGAGGAC, reverse: GTGGACAATCGG GGTGACAC (transcript size: 77 bp), IL-4: forward ATG
GGTCTCACCTCCCAACTGCT, reverse GTTTTCCAA CGTACTCTGGTTGGC (transcripts size: 506, 357, 405 bp) and IFN- $\gamma$ forward GAAGAATTGGAAAGAGGA, reverse CGACAGTTCAGCCATCAC (transcript size: 265 bp). Fluorescence readings at the end of the extension phase of each cycle were used to estimate the values for the threshold cycles $(\mathrm{Ct})$. The $\mathrm{Ct}$ values for each gene were converted into relative quantification $\left(2^{-\Delta \Delta C t}\right)$ using the machine 7500 v2.0.6 software. Samples of untreated and unstimulated cells were used as a calibrator for unstimulated treated cells samples. On the other hand, untreated stimulated samples were used as a calibrator for stimulated and treated cell samples. PCR negative control (with no template) was included for each pair of primers.

\section{Statistical analysis}

All data were expressed as means +/- standard deviations. Groups were compared using one-way ANOVA followed by Bonferroni's Multiple Comparison test, with a level of significance set at $p<0.05$. GraphPad Prism 5.0 software was used for all statistical analyses.

\section{Results}

Evaluation of the cytotoxicity of Allium sativum preparation to human PBMCs

In order to assess the immunomodulatory effect of the A.S. preparation, we started by evaluating cell toxicity of different doses of A.S.. Human PBMCs were treated with increasing doses of A.S. extract in the presence or the absence of stimulation (PHA or anti-CD3 mAb). Figure 1a shows that A.S. extract was not toxic to PBMCs at doses ranging between 0.5 and $4 \mu \mathrm{g} / \mathrm{ml}$. On the other hand, A.S. extract was found not toxic to PBMCs stimulated with PHA up to certain doses $(0.5$ to $2 \mu \mathrm{g} / \mathrm{ml})$. However, $4 \mu \mathrm{g} / \mathrm{ml}$ exhibited a significant toxicity to cells as shown in Fig. 1b. Similar pattern was observed with cells stimulated with anti-CD3 mAb (Fig. 1c). As a result, we concluded $4 \mu \mathrm{g} / \mathrm{ml}$ as a significantly toxic dose of A.S. extract to stimulated human PBMCs.

\section{Effect of Allium sativum preparation on PBMC Proliferation}

Subsequently, we tested the effect of the non toxic doses of A.S. extract on human PBMC proliferation by using CFSE combined to flow cytometry. To test whether A.S. is able to induce PBMC (more specifically CD4+ and CD8+ $\mathrm{T}$ lymphocytes) proliferation in the absence of mitogenic stimulation, unstimulated CFSE-labeled PBMCs were incubated with A.S. preparations at two doses (1 and $2 \mu \mathrm{g} / \mathrm{ml}$ ) for $96 \mathrm{~h}$. Our results showed that A.S. did not affect significantly $\mathrm{T}$ lymphocyte proliferation at the non toxic doses tested (Fig. 2 a, b, c, j, k, l; and Additional file 1: Figure S1a and c). In order to test whether A.S. is able to inhibit or enhance PHA or anti-CD3 -stimulated CD4+ 

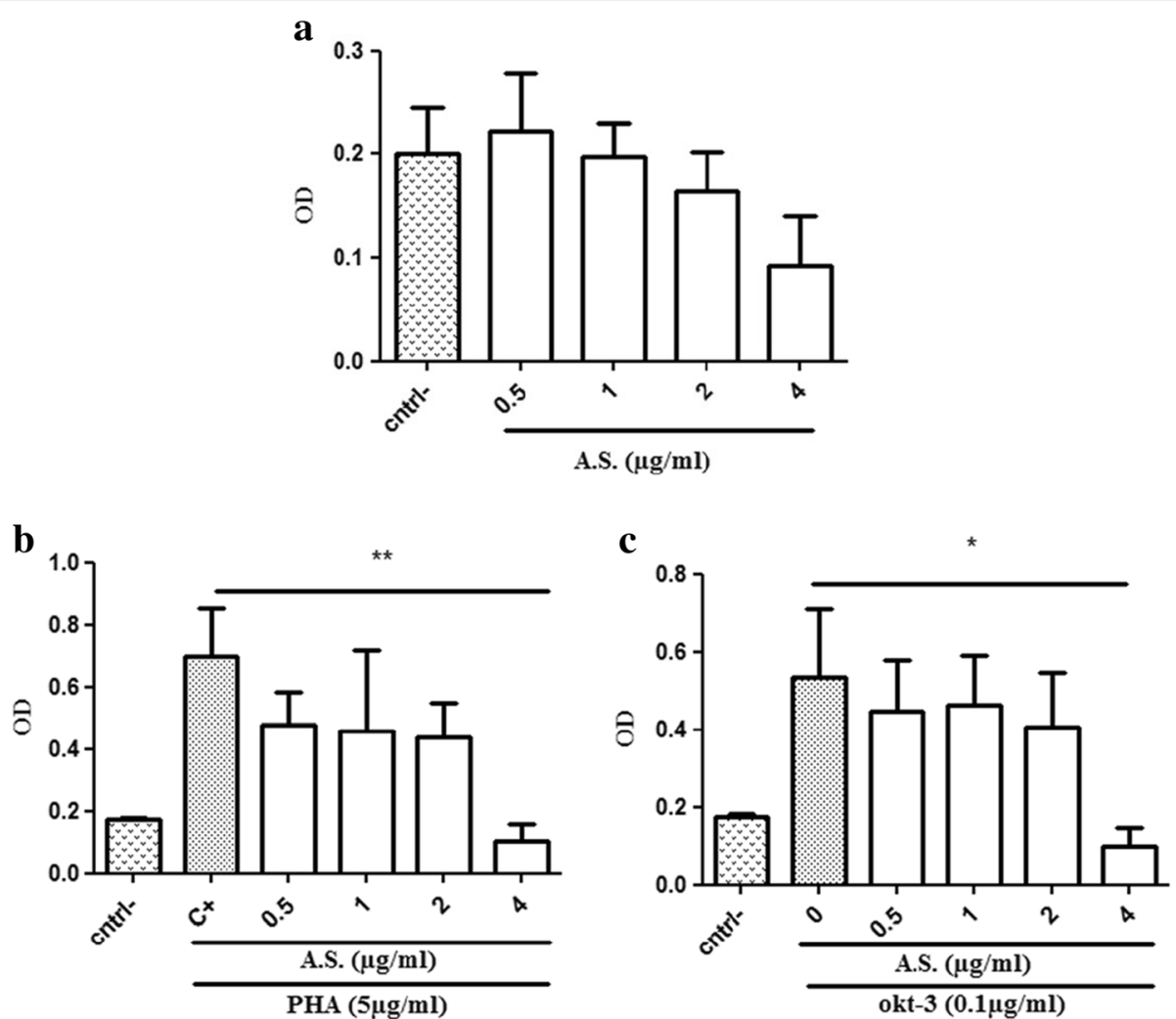

Fig. 1 Assessment of Allium sativum preparation cytotoxicity on human PBMCs. Human PBMCs were cultured for 4 days in the absence (cntrl-) or the presence of different doses of Allium sativum extract (a). In another series of experiments, PBMCs were left untreated or were treated with A.S. extract in the presence of PHA (b) or Okt-3 mAb (c). 4 days later, MTT assay was performed to evaluate cytotoxicity. Experiments shown in $\mathbf{a}, \mathbf{b}$ and $\mathbf{c}$ are representative of five, five and three independent experiments respectively. Data were analyzed using one way ANOVA test. (*, $\left.{ }^{* *}\right)$ indicate $P$ values of less than 0.05 and 0.01 respectively

and CD8+ T cells proliferation, CFSE-labeled PBMCs were stimulated by PHA or anti-CD3 mAb (Okt-3), in the absence or presence of A.S. extract (Fig. 2 d, e, f, m, n, o, g, h, i, p, q, r; and Additional file 1: Figure S1 a, b, c et d). These data showed that A.S. did not affect significantly CD4+ or CD8+ T lymphocyte proliferation.

\section{Significant regulation of IL-17 gene expression by Allium sativum}

To assess the effect of Allium sativum on pro- and antiinflammatory cytokine gene expression, we treated PBMCs from healthy donors, for $18 \mathrm{~h}$, with non toxic doses of A.S. preparation with or without PHA stimulation. Results in Fig. 3a indicate that a single treatment with A.S. extract stimulated significantly the expression of the pro-inflammatory cytokine, IL-17. We could detect an increased expression of IL-17 gene in 4 out of 6 donors tested. In all these 4 donors, we have observed an increase in IL-17 transcripts upon treatment with A.S.. Interestingly, when PBMCs were stimulated with PHA, treatment with A.S. showed a significant and dose dependent decrease in IL-17 gene expression (Fig. 3b). On the other hand, we could not detect any statistically significant effect of A.S. on
IL-4 gene expression (known to be an anti-inflammatory cytokine), either in the absence (Fig. 3c) or presence (Fig. 3d) of a T lymphocyte activator such as PHA. It is to note that a trend of increase in IL-4 gene expression was observed in some donors both in the absence (Fig. 3c) and the presence (Fig. 3d) of PHA, but this effect was not significant. We also tempted to quantify the expression of IFN- $\gamma$ gene in our experiments, but we could not detect its expression in our tested donors (data not shown); and thus no conclusions could be drawn for this cytokine. Altogether, these data suggested that A.S. preparation exhibited a significant regulation of IL-17 gene expression and that this effect would depend on the activation state of T lymphocytes.

\section{Analysis of polyphenols and flavonoids in Allium sativum extract by HPLC}

With the aim of identifying the bioactive compounds of Allium sativum extract responsible for the observed effect, A.S. ethanolic preparation was analyzed by HPLC at $285 \mathrm{~nm}$, to determine the presence of polyphenols and flavonoids. A mixture of seven standards was used in this experiment. Interestingly, three compounds, catechin, vanillic acid and ferulic acid, were identified 


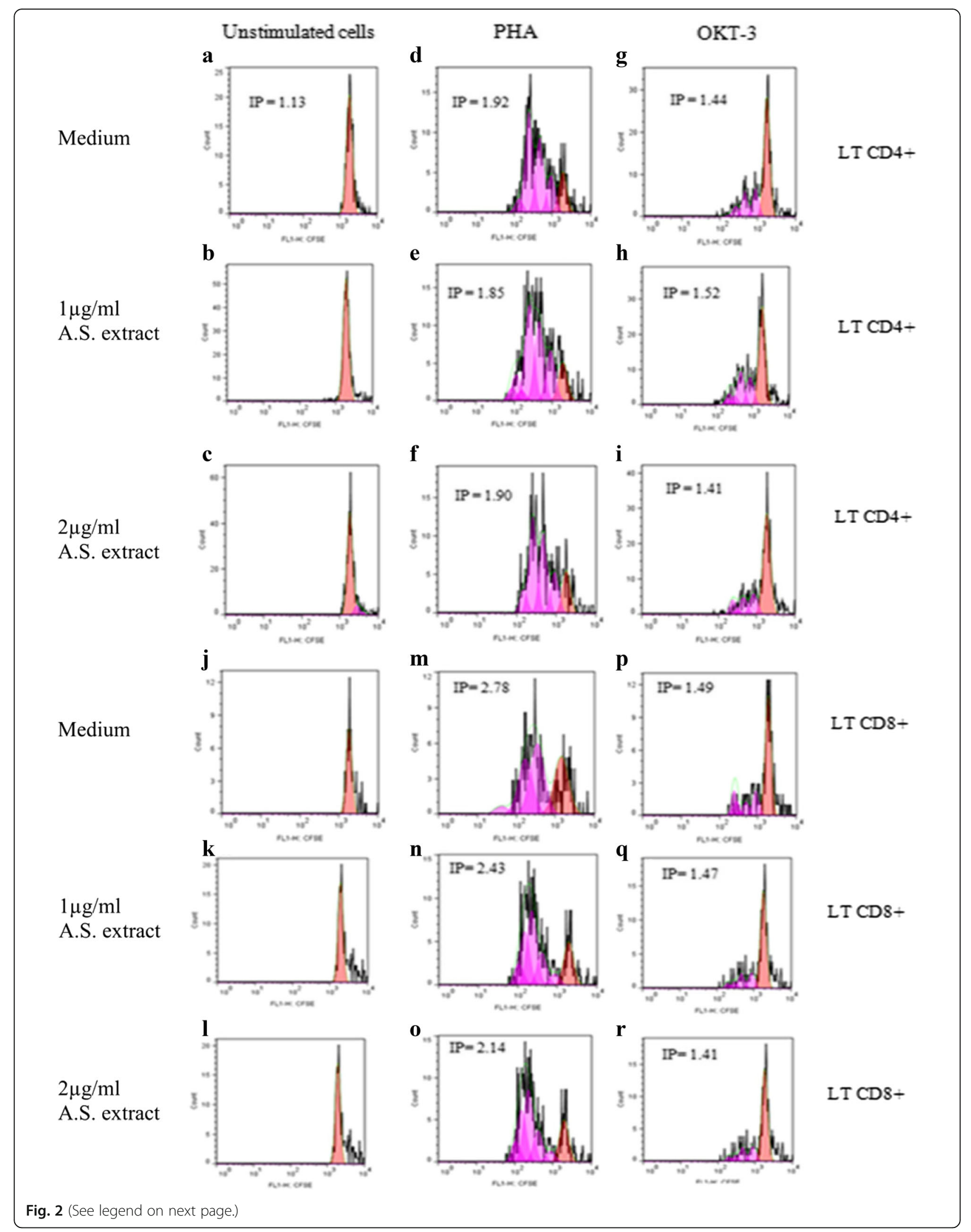


(See figure on previous page.)

Fig. 2 Effect of Allium sativum extract on human PBMCs proliferation. Panels from a to $\mathbf{i}$ show an example of data generated by CFSE and anti-CD4 stained PBMCs. Panels from $\mathbf{j}$ to $\mathbf{r}$ show an example of data generated by CFSE and anti-CD8 stained PBMCs. Cells were cultured in different conditions of stimulation and treated with two doses of Allium sativum (A.S.) extract for 4 days. $\mathbf{a}$ and $\mathbf{j}$ untreated PBMCs $\mathbf{b}$ and $\mathbf{k}$, $\mathbf{c}$ and I PBMCs treated with A.S. extract at 1 and $2 \mu \mathrm{g} / \mathrm{ml}$ respectively. $\mathbf{d}$ and $\mathbf{m}$ PBMCs stimulated with PHA. e and $\mathbf{n}, \mathbf{f}$ and $\mathbf{o}$ cells were stimulated with PHA and treated with A.S. extract at 0.5 and $1 \mu \mathrm{g} / \mathrm{ml}$ respectively. $\mathbf{g}$ and $\mathbf{p}$ cells were stimulated with Okt-3 mAb at $0.1 \mu \mathrm{g} / \mathrm{ml}$. $\mathbf{h}$ and $\mathbf{q}$, i and $\mathbf{r}$ PBMCs stimulated with Okt-3 $\mathrm{mAb}$ and treated with A.S. extract at 1 and $2 \mathrm{\mu g} / \mathrm{ml}$ respectively. Each peak represents a cycle of cell division. The curves generated by the CFSE profile were analyzed using the proliferation platform of the FlowJo software. Data shown represent results of 4 independent experiments. IP indicates index of proliferation calculated with FlowJo software

from the extract by matching their retention time against those of the standards. Peak assignment was confirmed by injection of standards. Figure 4a shows the HPLC chromatogram of a mixture of 7 polyphenol standards for peak comparison with the chromatogram of the A.S. extract (Fig. 4b). The HPLC chromatogram of A.S extract in Fig. 4b displayed 7 peaks detected at $285 \mathrm{~nm}$. Peaks 1, 2 and 6 were identified as catechin, vanillic acid and ferulic acid, respectively. The chemical structure of each of the identified compounds is elucidated in Fig. 4c.
To summarize, this study showed that A.S. extract contains compounds, which could be used in non toxic doses and without affecting $\mathrm{T}$ cell proliferation, to modulate IL-17 gene expression by significantly stimulating its expression in the absence of prior PBMC activation; and to significantly inhibit its expression when PBMCs are stimulated with a mitogen such as PHA. Interestingly, in the same experimental conditions, A.S. does not affect the expression of the anti-inflammatory cytokine, IL-4. Furthermore, these data showed that our A.S. extract contains 3 polyphenol compounds, catechin,
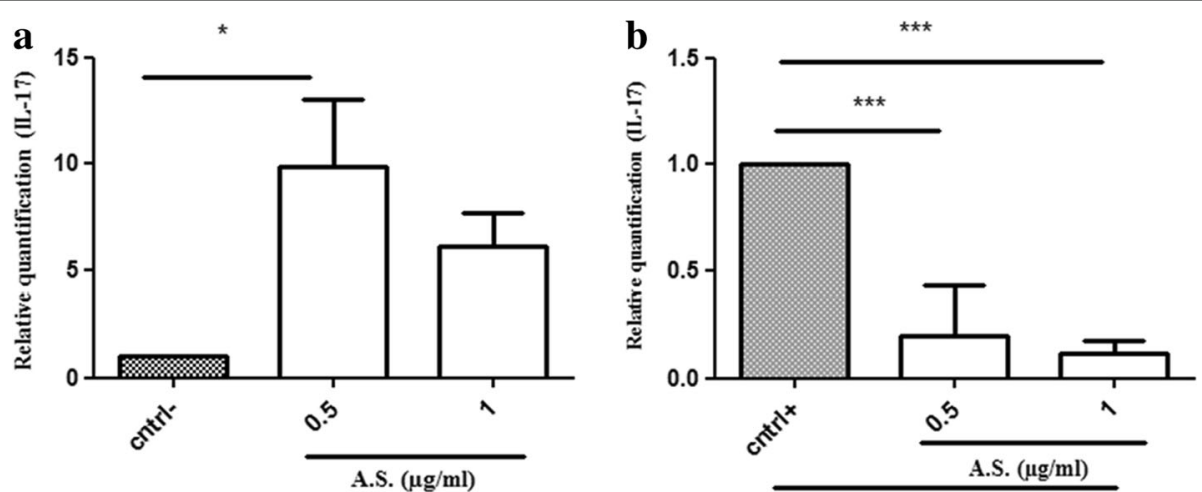

PHA $(5 \mu \mathrm{g} / \mathrm{ml})$
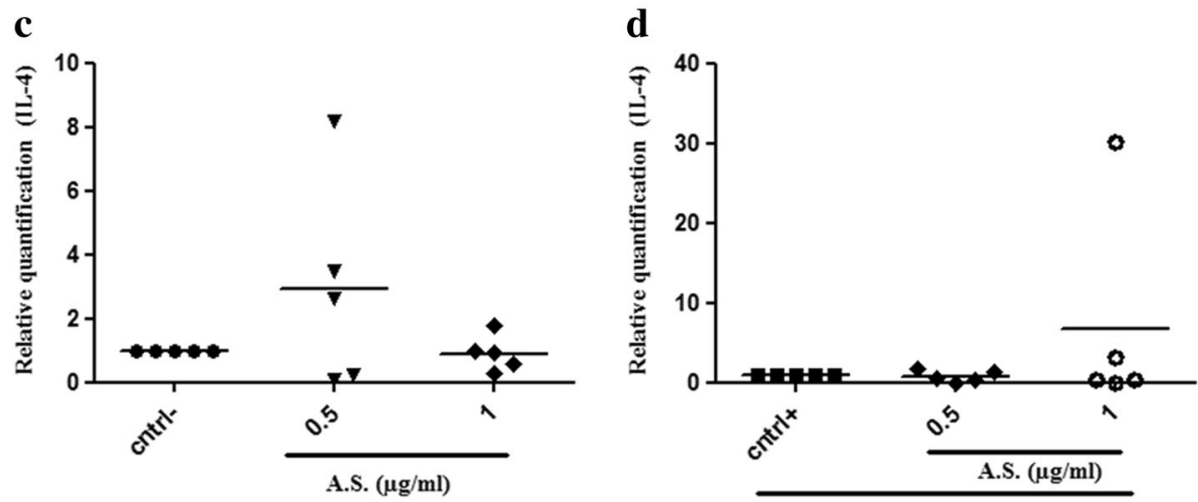

PHA $(5 \mu \mathrm{g} / \mathrm{ml})$

Fig. 3 Effects of Allium sativum extract on IL-17 and IL-4 gene expression in PBMCs. IL-17 (a) and IL-4 (c) transcripts were evaluated in PBMCs treated with two doses of A.S. IL-17 (b) and IL-4 (d) transcripts were assessed in PBMCs stimulated with PHA in the absence or presence of two doses of A.S.. Data were represented in mean \pm S.D. Data were analyzed using the one-way ANOVA test. $\left({ }^{*},{ }^{* * *}\right)$ indicate $P$ values of less than 0.05 and 0.001 respectively. Data shown in $a, b, c$ and $d$ are representative of four, three, five and five independent experiments respectively 


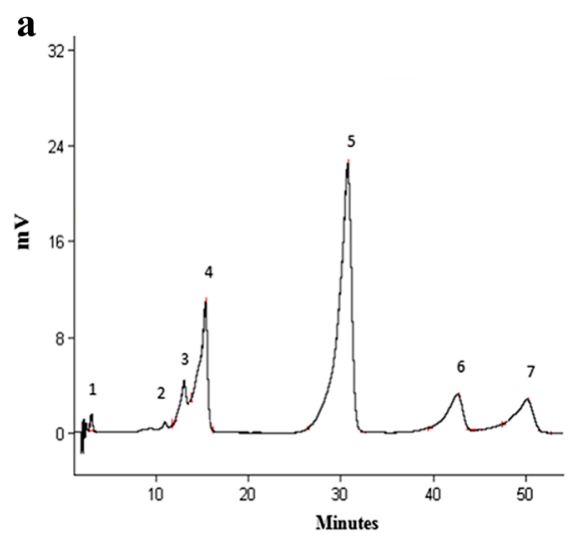

c

Catechin<smiles>Oc1cc(O)c2c(c1)O[C@H](c1ccc(O)c(O)c1)[C@H](O)C2</smiles>

b

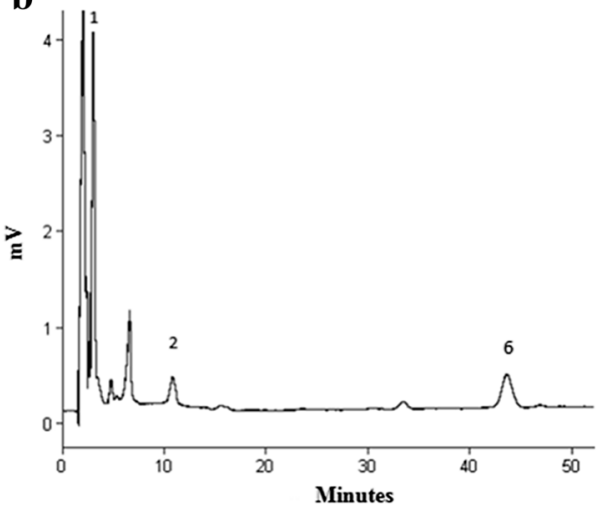

Ferulic acid
Vanillic acid<smiles>COc1cc(C(=O)O)ccc1O</smiles><smiles>COc1cc(/C=C/C(=O)O)ccc1O</smiles>

$\mathrm{HO}$

Fig. 4 a Chromatogram of 7 available polyphenol and flavonoid standards monitored at $280 \mathrm{~nm}$ and identified by retention time (minutes) 1: catechin, 2: vanillic acid, 3: cafeic acid, 4: syringic acid, 5: rutin, 6: ferulic acid, 7: vanillin. b HPLC chromatogram of A.S. extract obtained under optimum conditions: $88 \%$ water and $12 \%$ acetonitril, 50 min. Peak $n^{\circ}$. 1: catechin, 2: vanillic acid and 6: ferulic acid were identified. c The chemical structure of the three identified compounds

vanillic acid and ferulic acid, which could be responsible for this potentially interesting effect.

\section{Discussion}

For many years, A.S. has been acknowledged as an important folk medicine with a favorable effect against a large number of pathologic conditions. In this work, we aimed to evaluate the potential in vitro immunomodulatory effect of A.S., on PBMCs from healthy donors. We started by defining a range of non toxic doses using the MTT assay. These doses were used to evaluate cell proliferation and to quantify pro and anti-inflammatory cytokine gene expression. Our data showed that doses from 0.5 to $2 \mu \mathrm{g} / \mathrm{ml}$ of A.S. ethanolic extract were not toxic to cells under any of the used conditions. The same doses were used to test whether our A.S. extract exhibited any effect on PBMCs proliferation. Our results showed that A.S. extract did not affect neither human CD4+ nor CD8+ T cell proliferation induced by PHA, as shown by flow cytometry, which is consistent with data reported by others [16] when cells were stimulated by PHA. While in the same time, other data showed divergent results. Since Morioka et al. showed that A.S. extract enhanced ConA-induced proliferation of human $\mathrm{T}$ lymphocytes [16]. Other data revealed that several organosulfur compounds extracted from A.S. displayed a cell proliferation modulation, such as ajoene that exerted a strong inhibitory effect on PHA, phorbol myristate acetate and anti-CD3 mAb -induced proliferation of human lymphocytes [22, 23]. Colic et al. also demonstrated that a protein fraction from A.S. aqueous extract exhibited an enhancement of T-cell proliferation in mouse splenocyte cultures stimulated with PHA. As further explained in $[24,25]$, A.S. extracts and their compounds had a dual role on mice and rat $\mathrm{T}$ lymphocyte proliferation. In fact, higher concentrations $(50 \mu \mathrm{g} / \mathrm{ml})$ inhibited $\mathrm{T}$ cell proliferation triggered by ConA and at lower concentrations $(3-12.5 \mu \mathrm{g} / \mathrm{ml})$ of the extract, amplified the ConA-induced proliferative response of $\mathrm{T}$ cells [25]. It was also well demonstrated that aged A.S. extract enhanced the proliferation of spleen cells. Aged A.S. extract slightly improved ConA- induced proliferation of mice spleen cells, but did not increase the effects of the other mitogens, pokeweed mitogen (PWM) and lipopolysaccharides (LPS) [26]. This divergence might depend on different stimulation types, on the cell type used, and the A.S. preparation method used during these experiments.

As for cytokine gene expression, we could not detect any significant effect on IL-4 gene expression. While previous studies reported an increase in IFN- $\gamma$ and IL-4 production in lymphocytes from rat spleens upon oral A.S. consumption [27]; and an increase in IL-4 when lymphocytes from rat spleens were stimulated by phorbol 
myristate acetate and treated with aqueous and ethanol preparations made from garlic powder [28]. A.S. powder extracts were found to reduce the level of pro-inflammatory cytokines, IL-1 $\beta$ and TNF $\alpha$, in human blood sample supernatants, while the expression of the anti-inflammatory cytokine IL-10 was unchanged [29].

Our present study is the first report showing the ability of A.S. compounds to inhibit IL-17 gene expression. The present data showed an inhibition of the pro-inflammatory cytokine, IL-17 gene expression without affecting the antiinflammatory cytokine IL-4, which might suggest a specific potential regulation of IL-17 that could be useful in controlling several inflammatory and autoimmune diseases, such as multiple sclerosis, rheumatoid arthritis and cancer. For example, it was shown that IL-17 plays a pivotal role in the development of central nervous system inflammation in multiple sclerosis, where it was found to correlate with active lesions [30] and to be up-regulated in chronic lesions in multiple sclerosis patients [31, 32]. IL-17 was also shown to be involved in the pathogenesis of rheumatoid arthritis [33]. Indeed, a high level of IL-17 was found in synovium and synovial cultures from rheumatoid arthritis patients [34, 35]. IL-17 appeared to activate and enhance all mechanisms of tissue injury and to up-regulate and/or synergize with local inflammatory mediators such as IL-6 $[36,37]$, IL- $1 \beta$ and TNF- $\alpha[37,38]$. Furthermore, there are suggestions that in pulmonary asthma there are higher levels of intracellular IL-17 and increased numbers of IL-17producing cells ( $\mathrm{T}$ lymphocytes and eosinophils in broncheoalveolar lavage) relative to healthy controls both locally and within the circulation [39]. Higher amounts of IL-17 has also been revealed in many different types of human tumors including lymphoma, melanoma, breast, colon, gastric, hepatocellular, pancreatic, ovarian and prostate cancers. Overall, the presence of Th17 cells and/or IL-17 has been reported to be a poor prognostic indicator [40]. Similar observations have also been made in different mouse models of cancer [40]. Wilke et al. explained how IL-17 has become an interesting therapeutic target in many autoimmune diseases [41].

Because there is an ongoing debate concerning whether organosulfur compounds or other constituents such as polyphenols and flavonoids, mediate the protective effect attributed to garlic [29], we carried out a qualitative analysis of the A.S. extract by HPLC. This showed the presence of two phenolic acids "vanillic acid and ferulic acid" and a flavonoid of the flavonols class which is "catechin". These phenolic compounds are known to have interesting immunomodulatory effects but none of them was tested on the expression of IL-17 from human PBMC. Vanillic acid, which is a benzoic acid derivative and an oxidized form of vanillin formed during the transformation of vanillin to ferulic acid [42-44], has been proved to enhance the activity of lymphocyte proliferation and
IFN- $\gamma$ secretion in human PBMCs [45] and to exhibit a hepatoprotective effect by its suppressive action on immunemediated liver inflammation in ConA-induced liver injury in mouse $[44,46]$. As for ferulic acid, it was found to have a chemopreventive activity against coronary heart disease, thrombosis, mutagenesis and carcinogenesis, in addition to an anti-cancer activity against colon and rectal cancer [47]. Catechin is a major compound of flavonoids, which are known for their ability to control lymphocyte proliferation and to modulate IL- 2 and IFN- $\gamma$ secretion in human PBMCs and mouse splenocytes [48]. It was also found that catechin ameliorates cardiac dysfunction, in a rat model of chronic heart failure, by regulating the unbalanced level of IL-17/IL-10 [49].

\section{Conclusion}

Allium sativum $L$. preparation exhibiting a specific inhibition of the pro-inflammatory cytokine IL-17, without affecting cell proliferation in human PBMCs indicates a potential valuable effect of the compounds present in this plant to treat inflammatory diseases and cancer, where IL-17 is highly involved. The individual contribution of these identified compounds to this interesting global inhibitory effect is under investigation and could unravel a pivotal therapeutic role.

\section{Additional files}

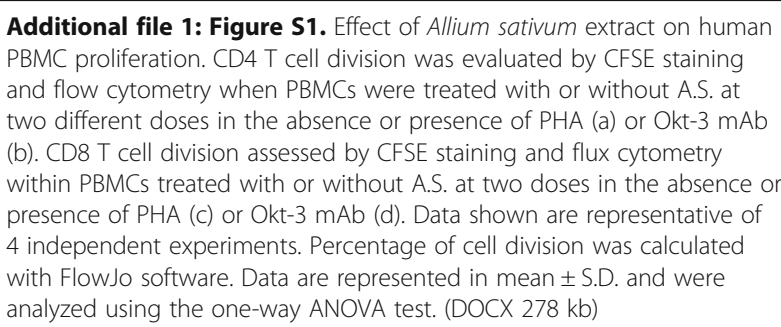

Additional file 1: Figure S1. Effect of Allium sativum extract on human PBMC proliferation. CD4 T cell division was evaluated by CFSE staining and flow cytometry when PBMCs were treated with or without A.S. at two different doses in the absence or presence of PHA (a) or Okt-3 mAb (b). CD8 T cell division assessed by CFSE staining and flux cytometry within PBMCs treated with or without A.S. at two doses in the absence or presence of PHA (c) or Okt-3 mAb (d). Data shown are representative of 4 independent experiments. Percentage of cell division was calculated with FlowJo software. Data are represented in mean \pm S.D. and were analyzed using the one-way ANOVA test. (DOCX $278 \mathrm{~kb}$ )

Additional file 2: Raw data of MTT assays. (XLSX $10 \mathrm{~kb}$ )

Additional file 3: Raw data of cell proliferation using flow cytometry. (XLSX $14 \mathrm{~kb}$ )

Additional file 4: Raw data of gene expression by real time RTPCR. (XLSX $17 \mathrm{~kb}$ )

\section{Abbreviations \\ A.S.: Allium sativum L.; ARNm: ARN messenger; CFSE: 5, 6-carboxyfluorescein diacetate succinimidyl ester; Con A: Concanavalin A; Ct: Threshold cycles; IL: Interleukin (e.g., IL-4, IL-17); mAb: Monoclonal antibody; MTT: 3-(4, 5 dimethylthiazol-2-yl)-2, 5 diphenyltetrazolium bromide; PBMCs: Peripheral blood mononuclear cells; PHA: Phytohaemagglutinin; Th: T helper}

\section{Acknowledgement}

We would like to thank Dr. Ouahman Lahcen from the Biology department of the Polydisciplinary Faculty of Safi, Morocco for his help with the identification of Allium sativum L.

\section{Funding}

This study has been funded by the ministry of higher education and scientific research, Rabat, Morocco. 


\section{Availability of data and materials}

Datasets supporting the conclusions of this article are represented in the manuscript and the included Additional files 2, 3 and 4.

\section{Authors' contributions}

MM carried out cell culture, data acquisition, analysis of cytotoxicity assays, cell proliferation, gene expression assays and statistical analysis. FS helped with the CFSE cell proliferation assays. OA helped with the MTT assays. AE, $\mathrm{AA}$ and $\mathrm{JJ}$ carried out the HPLC analysis. ABE collected A.S. samples and prepared the extract. SN contributed to real time PCR experiments. $\mathrm{NH}$ participated in study design and coordination and helped to draft the manuscript. AB conceived the study, participated in its design and coordination and helped to draft the manuscript. All authors read and approved the final manuscript.

\section{Authors' information}

MM is a PhD student at the Faculty of Medicine and Pharmacy, Hassan II University, Casablanca, Morocco. FS is a researcher and Cellular immunology Laboratory supervisor at the National Institute of Hygiene, Rabat, Morocco. $\mathrm{OA}$ is a PhD student at the Cellular and Molecular Pathology Laboratory, Faculty of Medicine and Pharmacy, Hassan II University, Casablanca, Morocco. ABE is a PhD student at Cadi Ayyad University, Polydisciplinary Faculty - Safi, Morocco. AE and AA are PhD students and $\mathrm{JJ}$ is a professor of chemistry at the Faculty of Sciences Ain Chock, Hassan II University, Casablanca, Morocco. SN is a Professor of Genetics at the Faculty of Medicine and Pharmacy, Hassan II University, Casablanca, Morocco. $\mathrm{NH}$ is a Professor of Immuno-hematology at the Faculty of Medicine and Pharmacy, Hassan II University, Casablanca, Morocco. AB is a Professor of Immunology at the Faculty of Medicine and Pharmacy, Hassan II University, Casablanca, Morocco.

\section{Competing interests}

The authors declare that they have no competing interests.

\section{Consent for publication}

Not applicable

\section{Ethics approval and consent to participate}

Informed consent was obtained from all donors for the use of their blood for scientific research. This study was approved by the ethic committee for biomedical research affiliated to the Faculty of Medicine and Pharmacy, Hassan II University, Casablanca, Morocco, under the reference number 0216.

\section{Author details \\ 'Laboratory of Hematology and Cellular and Genetic Engineering, Faculty of Medicine and Pharmacy, Hassan II University, Casablanca, Morocco. ${ }^{2}$ Laboratory of Experimental Medicine and Biotechnology, Faculty of Medicine and Pharmacy, Hassan II University, Casablanca, Morocco. ${ }^{3}$ Laboratory of Cellular Immunology, National Institute of Hygiene, Rabat, Morocco. ${ }^{4}$ Cellular and Molecular Pathology Laboratory, Faculty of Medicine and Pharmacy, Hassan II University, 19 Rue Tarik Ibnou Ziad, B.P. 9154 Casablanca, Morocco. ${ }^{5}$ Laboratory of Synthesis, Extraction and Physicochemical Study of Organic Molecules, Faculty of Sciences Ain Chock, Hassan II University, Casablanca, Morocco. ${ }^{6}$ Research Team Health and Environment, Cadi Ayyad University, Polydisciplinary Faculty, Safi, Morocco.}

Received: 17 June 2016 Accepted: 9 September 2016 Published online: 29 September 2016

\section{References}

1. Gonzales JR, Groger S, Boedeker RH, Meyle J. Expression and secretion levels of Th1 and Th2 cytokines in patients with aggressive periodontitis. Clin Oral Investig. 2012;16(5):1463-73.

2. Lang A, Lahav M, Sakhnini E, Barshack I, Fidder HH, Avidan B, Bardan E, Hershkoviz R, Bar-Meir S, Chowers Y. Allicin inhibits spontaneous and TNF-alpha induced secretion of proinflammatory cytokines and chemokines from intestinal epithelial cells. Clin Nutr. 2004;23(5):1199-208.

3. Hirahara K, Poholek A, Vahedi G, Laurence A, Kanno Y, Milner JD, O'Shea J. Mechanisms underlying helper T-cell plasticity: implications for immunemediated disease. J Allergy Clin Immunol. 2013;131(5):1276-87.

4. Pulendrani B, Artis D. New paradigms in type 2 immunity. Science. 2012;337:431-5.
5. Kaku H, Goldstein IJ, Van Damme EJM, et al. New mannose-specific lectins from garlic (Allium sativum) and ramsons (Allium ursinum) bulbs. Carbohydr Res. 1992;229:347-53.

6. Pelletier M, Maggi L, Micheletti A, Lazzeri E, Tamassia N, Costantini C, Cosmi L, Lunardi C, Annunziato F, Romagnani S, et al. Evidence for a cross-talk between human neutrophils and Th17 cells. Blood. 2010;115:2.

7. Singh VK, Singh DK. Pharmacological effects of garlic (Allium sativum L.) Ann Rev Biomed Sci. 2008;10:6-26.

8. Oukka M. Th17 cells in immunity and autoimmunity. Ann Rheum Dis. 2008; 67 Suppl 3:iii26-9.

9. Fouser LA, Wright F, Dunussi-Joannopoulos K, Collins M. Th17 cytokines and their emerging roles in inflammation and autoimmunity. Immunol Rev. 2008:226:87-102.

10. Kemper K. Garlic (Allium sativum), The Longwood Herbal Task Force and the Center for Holistic Pediatric Education and Research. 2000. p. 49.

11. Londhe VP, Gavasane AT, Nipate SS, Bandawane DD, Chaudhari PD. Role of garlic (allium sativum) in various diseases: an overview. J Pharm Res Opin. 2011;1(4):129-34.

12. Banerjee S, Mukherjee P, Maulik S. Garlic as an antioxidant: the good, the bad and the ugly. Phytother Res. 2003;17:97-106.

13. Corzomartinez M, Corzo N, Villamiel M. Biological properties of onions and garlic. Trends Food Sci Technol. 2007;18(12):609-25.

14. Suleria HAR, Butt MS, Anjum FM, Sultan S, Khalid N. Aqueous garlic extract; natural remedy to improve haematological, renal and liver status. J Nutr Food Sci. 2013;4:252

15. Lanzotti V. The analysis of onion and garlic. J Chromatogr. 2006;1112(1-2): $3-22$.

16. Pranoto Y, Salokhe V, Rakshit S. Physical and antibacterial properties of alginate based edible film incorporated with garlic oil. Food Res Int. 2005; 38(3):267-72.

17. Sivam GP. Protection againstHelicobacterpyloriand other bacterial infections by garlic. J Nutr. 2001:131(3):1106s-8.

18. Ota N, Takano F, Muroga S, Kawabata T, Ishigaki Y, Yahagi N, Ohta T. Garlic extract and its selected organosulphur constituents promote ileal immune responses ex vivo. J Funct Foods. 2012;4(1):243-52.

19. Moutia M, El Azhary K, Elouaddari A, Al Jahid A, Jamal Eddine J, Seghrouchni F, Habti N, Badou A. Capparis Spinosa L. promotes antiinflammatory response in vitro through the control of cytokine gene expression in human peripheral blood mononuclear cells. BMC Immunol. 2016;17(1):26.

20. Somani SJ, Modi KP, Majumdar AS, Sadarani BN. Phytochemicals and their potential usefulness in inflammatory bowel disease. Phytother Res. 2015; 29(3):339-50.

21. Amedei A, Prisco D, D'Elios MM. Multiple sclerosis: the role of cytokines in pathogenesis and in therapies. Int J Mol Sci. 2012;13(10):13438-60.

22. Amagase $\mathrm{H}$. Clarifying the real bioactive constituents of garlic. J Nutr. 2006; 136:716S-25.

23. Liu JZ, Lin XY, Milner JA. Dietary garlic powder increases glutathione content and glutathione S-transferase activity in rat liver and mammary tissues. FASEB J. 1992;6:A3230.

24. Chung LY. The antioxidant properties of garlic compounds: allyl cysteine, Allicin and allyl disulfide. J Med Foods. 2006;9:205-13.

25. Colic M, Vucevic D, Kilibarda V, Radicevic N, Savic M. Modulatory effects of garlic extracts on proliferation of T-lymphocytes in vitro stimulated with concanavalin A. Phytomedicine. 2002:9(2):117-24.

26. Ide N, Lau BHS. Garlic compounds minimize intracellular oxidative stress and inhibit nuclear factor -KB activation. J Nutr. 2001;131:1020s-6.

27. Zamani A, Vahidinia A, Ghannad MS. The effect of garlic consumption on Th1/Th2 cytokines in phytohemagglutinin (PHA) activated rat spleen lymphocytes. Phytother Res. 2009;23(4):579-81.

28. Colic M, Vucevic D, Kilibarda V, Radicevic N, Savic M. Garlic extracts stimulate proliferation of rat lymphocytes in vitro by increasing il-2 and il-4 production. Immunopharmacol Immunotoxicol. 2000;22(1):163-81.

29. Keiss H-P, Dirsch VM, Hartung T, Haffner T, Trueman L, Auger J, Kahane R, Vollmar AM. Garlic (Allium sativum L.) modulates cytokine expression in lipopolysaccharide-activated human blood thereby inhibiting NF-B activity. J Nutr. 2003;133:2171-5.

30. Lau BHS. Detoxifying, radioprotective and phagocyte enhancing effects of garlic. Int Clin Nutr Rev. 1989;9:27-31.

31. Morioka N, Szel LL, Morton DL, Irie RF. A protein fraction from aged garlic extract enhances cytotoxicity and proliferation of human lymphocytes 
mediated by interleukin-2 and concanavalin A. Cancer Immunol Immunother. 1993;37:316-22.

32. Kuttan G. Immunomodulatory effect of some naturally occuring sulphurcontaining compounds. J Ethnopharmacol. 2000;72(1-2):93-9.

33. Feng ZH, Zhang GM, Hao TL, Zhou B, Zhang H, Jiang ZY. Effect of diallyl trisulfide on the activation of $\mathrm{T}$ cell and macrophage-mediated cytotoxicity. J Tongji Med Univ. 1994;14:142-7.

34. Romano EL, Montaño RF, Brito B, Apitz R, Alonso J, Romano M, Gebrán S, Soyano A. Effects of Ajoene on lymphocyte and macrophage membranedependent functions. Immunopharmacol Immunotoxicol. 1997;19:15-36.

35. Dorhoi A, Dobrean V, Zahan M, Virag P. Modulatory effects of several herbal extracts on avian peripheral blood cell immune responses. Phytother Res. 2006;20(5):352-8.

36. Gazzinelli RT, Oswald IP, James SL, Sher A. IL-10 inhibits parasite killing and nitrogen oxide production by IFN- - activated macrophages. J Immunol. 1992;148(6):1792-6.

37. Larypoor M, Bayat M, Zuhair MH, Akhavan Sepahy A, Masoud A. Evaluation of the number of CD4+CD25+ FoxP3+ Treg cells in normal mice exposed to AFB1 and treated with aged garlic extract. Cell J (Yakhteh). 2013;15:1.

38. Sela U, Ganor S, Hecht I, Brill A, Miron T, Rabinkov A, Wilchek M, Mirelman D, Lider O, Hershkoviz R. Allicin inhibits SDF-1alpha-induced T cell interactions with fibronectin and endothelial cells by down-regulating cytoskeleton rearrangement, Pyk-2 phosphorylation and VLA-4 expression. Immunology. 2004;111(4):391-9.

39. Ebrahimi M, Hassan ZM, Mostafaie A, Mehrjardi NZ, Ghazanfari T. Purified protein fraction of garlic extractmod- ulates cellular immune response against breast transplanted tumors in BALB/c mice model. Cell J. 2013;15(1):65-74.

40. Lau BH, Yamasaki T, Gridley DS. Garlic compounds modulate macrophage and T-lymphocyte functions. Mol Biother. 1991;3:103-7.

41. Nantz MP, Rowe CA, Muller CE, Creasy RA, Stanilka JM, Percival SS. Supplementation with aged garlic extract improves both NK and gd-T cell function and reduces the severity of cold and flu symptoms: a randomized, double-blind, placebo-controlled nutrition intervention. Clin Nutr. 2012:31(3):337-44.

42. Ried K, Frank OR, Stocks NP. Aged garlic extract lowers blood pressure in patients with treated but uncontrolled hypertension: a randomised controlled trial. Maturitas. 2010;67(2):144-50.

43. Morihara N, Ide N, Weiss N. Aged garlic extract inhibits homocysteineinduced scavenger receptor CD36 expression and oxidized low-density lipoprotein cholesterol uptake in human macrophages in vitro. J Ethnopharmacol. 2011;134(3):711-6.

44. Sitia S, Tomasoni L, Atzenietal F. From endothelial dysfunction to atherosclerosis. Autoimmun Rev. 2010;9(12):830-4

45. Lumeng CN, Deyoung SM, Bodzin JL, Saltiel AR. Increased inflammatory properties of adipose tissue 13 macrophages recruited during diet-induced obesity. Diabetes. 2007;56(1):16-23.

46. Liu J, Divoux A, Sun J, et al. Genetic deficiency and pharmacological stabilization ofmast cells reduce diet-induced obesity and diabetes in mice. Nat Med. 2009:15(8):940-5.

47. Liu C, Cao F, Tang QZ, Yan L, Dong YG, Zhu LH, Wang L, Bian ZY, Li H. Allicin protects against cardiac hypertrophy and fibrosis via attenuating reactive oxygen species-dependent signaling pathways. J Nutr Biochem. 2010;21(12):1238-50.

48. Quintero-Fabi'and S, Ortũno-Sahag'un D, V'azquez-Carrera M, Lopez-Roa RI. Alliin, a garlic (Allium sativum) compound, prevents LPS-induced inflammation in 3T3-L1 adipocytes. Mediators Inflamm. 2013;2013:11.

49. Hotamisligil GS. Inflammation and metabolic disorders. Nature. 2006 444(7121):860-7.

\section{Submit your next manuscript to BioMed Central and we will help you at every step:}

- We accept pre-submission inquiries

- Our selector tool helps you to find the most relevant journal

- We provide round the clock customer support

- Convenient online submission

- Thorough peer review

- Inclusion in PubMed and all major indexing services

- Maximum visibility for your research

Submit your manuscript at www.biomedcentral.com/submit 